\title{
Cells per Microliter
}

National Cancer Institute

\section{Source}

National Cancer Institute. Cells per Microliter. NCI Thesaurus. Code C67242.

A unit of cell concentration expressed as a number of cells per unit volume equal to one microliter. 